\title{
古代日本に扔ける建物の維持管理に対する公的概念の萌芽と修理体制 THE GERM OF PUBLIC CONCEPT FOR BUILDING MAINTENANCE AND ITS ESTABLISHMENT IN ANCIENT JAPAN
}

\author{
海 野 聡* \\ Satoshi UNNO
}

\begin{abstract}
This study aims at the germ of public concept to building maintenance and the maintenance organization in ancient Japan. The aims of this article are below. 1. The resolution of the germ time of public concept to building maintenance 2. The establishment of maintenance in ancient period As a result, the public concept of building maintenance appeared in Tenpyo Period, and the maintenance organization was established in the latter half of Nara period. And I re-assembled the document about the unification and abolition of construction organization in Heian Period.
\end{abstract}

Keywords : Nara Period, public concept to maintenance, repair,Suri-shiki, Moku-Ryo, establishment of building maintenance 奈良時代, 維持管理の公的概念, 修理, 修理職, 木工寮, 修理体制

1.はじめに

これまでに古代の律令制度下における造営体制・生産組織が明ら かにされてきた注1)。また奈良時代の寺院の財産を書き上げた資財 帳や縁起などをもとに、伽藍の復原や建物の構造や規模などが解明 されてきた注2)。こうした先行研究の成果は奈良時代の新規造営の 側面を描いているが、完成後の建物の維持管理については、松原弘 宣氏が奈良時代から 10 世紀の修理組織について指摘する程度で注3)、 ほとんど目が向けられてこなかった。加えて、いずれの研究も地方 に対する検討は不十分である。筆者も奈良時代の造営体制を論じて きたが、新造を主な対象としてきた。建物の維持管理については、 国分寺における維持管理注 4 ) や平安時代の宇治院資財帳写や広隆寺 資財交替実録帳の維持管理の記述注 5) を指摘しており、また前稿で 建物の維持管理に関する法的な規定を整理している注6)。

本稿では、前稿の成果を受けて、奈良時代を中心に、7〜9世紀 の文献資料の検討を通して、建物の維持管理に対する公的概念が生 じた時期と奈良時代〜 9 世紀における修理体制及びその職務の解明 を目的とする。なお対象とする文献資料は古代文献史学の基礎資料 であるため、個々の典籍については記述を省略する。また建物の維 持管理体制時における資財帳の利用実態の解明も課題として生じる が、これについては稿を改めたい。

\section{2. 建物の維持管理に対する公的概念の変化}

\section{1。法制による規定}

古代には法的な規定により、建物の維持管理を図っており、これ については、前稿で詳述したが注7)、本稿の考察の下地であるため、 その概略を述べたい。
古代日本の法令の根幹は律令であり、7 世紀後半に先駆的な律令 である飛鳥浄御原令が制定され、その後、大宝律令・養老律令が施 行された。大宝律令は大宝元年（701）に完成し、同 2 年（702）施 行されたが、全文が散逸している注8)。また養老律令は養老 2 年 (718) に撰定を開始し、天平勝宝 9 歳（757）に施行された注9)。養老律令 の完成時期は諸説あるが、養老年間（717～724）には完成したとさ れる。養老律令も現存しないが、『令集解』『令義解』やその他の史 料からほとんどが復元されている。先行研究によると、この両律令 の違いは、わずかであるとされる注10)。

律令以外には、令文を補足するための「例」、律令の修正・補足の ための法令（副法）である「格」、律令の施行細則である「式」があ り、これらが律令を補完していた。

早いものでは、養老 4 年 $(720)$ 頃に令文を補足する『八十一例』 が撰定されている。この「例」の詳細は不明であるが、役所ごとの 施行細則編纂で、式と同様に、令文の不備を補い、解釈を明確化し ようとしたものであった注11)。これらの令文やこれを補足する細則 には建物の維持管理に関する規定はなされなかった。またこの時期 の太政官符などに、維持管理に関する個別の通達は確認できない。

このように養老律令の段階、すなわち 8 世紀前半には建物の維持 管理の規定はなかったと考えられる。この時期には平城宮において も朝堂院をはじめ、ほとんどの建物が掘立柱建物であり、一部の寺 院を除いて、礎石建物は少なく、多くは永続性を持たなかった。こ うした発掘より示される建物の状況は、長期的な維持管理の規定を 設けなかった状況とも合致する。

格式をみると、寺院に関しては 8 世紀中頃、神社・官舎に関して は 8 世紀末〜 9 世紀初頭にかけて、修理の記述が確認でき、この時 
期には、災害等などに対する個別の修理対応から、全国的な法整備 による建物の維持管理体制の確立へと変化したことが確認できる。 すなわち、この法制化される 8 世紀中頃までに、建物の維持管理に 対する概念が芽生えたのである。中でも寺院や正倉が早い時期に対 象となった背景には、これらの施設の礎石化が比較的早く、建築の 長寿命化が進んだことがあったと考えられる。

\section{2. 建物の維持管理に対する公的概念の萌芽}

法制史料以外にも、7 世紀から個別の修理に関する記載が確認で きる。これらの法制史料以外の記述を含め、建物の維持管理に対す る概念の変化に焦点を当てたい。

『日本書紀』天武天皇 10 年（681）正月 19 日条には、畿内・諸 国に詔して、諸々の社殿の修理を命じたことが記される。ここでの 「修理」は、建物の維持管理のみではなく、神社境域の復興や社殿 の整備の意を多く含むと考えられる。

『続日本紀』文武 2 年（698）8 月 20 日条・同年 12 月 21 日条・ 文武 3 年 (699) 9 月 15 日条には高安城・石船柵など、軍事関係の 施設の修理が確認できる。これらの軍事施設には建物も含まれよう が、前稿で指摘した『軍防令』の規定のように、防衛上・戦略上、 重要な堀や土㲦などが主な対象と推察できる。また維持管理という 点では、『続日本紀』文武 3 年（699）10月 20 日条に山稜が修理・ 造営されたことが記される。

しかしこれらの維持管理の事例は建物ではなく、主に土塁や山稜 など、土木構築物に対するものである。維持管理の主対象が建物と 推察されるものとしては、天平 7 年 (735) の記述が初出である。

『続日本紀』天平 7 年 (735) 6 月 5 日条

栜曰。先令并寺者。自今以後。更不須并。宜令寺寺務加修造。

若有解急不肯造成者。准前并之。其既并造記。不煩分拆。

内容は以下のとおりである。霊亀 2 年（716） 5 月 15 日（『続日 本紀』）に出さ机た「先令」では、粗末な寺院が多く、造営が行われ ないため、貧弱な寺院を併合させた。しかし今後は、これ以上の併 合を禁じ、それぞれの寺に可能な限り、修繥を加えるべきである。 もし寺や寺を支えるべき檀越が修造に勤しまない場合には、これま で通り、合併せよ。すでに併合して、修造が済んでいるならば、分 離せずともよい。

「先令」(『続日本紀』霊亀 2 年（716） 5 月 15 日条) を定めた際 には、寺院の荒廃に対して、修理・修復という方法ではなく、併合 して寺を造立するという措置が講じられた。これは養老律令に建物 の維持管理に関する規定がないという背景と同じく、建物の維持管 理に対する概念が見られないことに起因する。これに対し、天平 7 年（735）の栜に見える修繥には、再整備の意味も含まれると考元 られ、既存建物の修理であるかは定かではないが、建物の計画的な 維持管理に対する意志の表出と捉えられる。

『正倉院文書』における建物の修理に関する初出は天平 10 年 （738）の「駿河国正税帳」(『大日本古文書』編年 2 ノ 106) で、 正倉を対象に、「新造」と「修理」の記述があり、寺だけではなく、 官衙についても、修理が求められたことがわかる。この文書は、正 倉の状態を具体的に表しており、天平 7 年（735）の勅以上に、明 確かつ具体的に、修理による建物の維持管理の様子を示している。

また弘仁 5 年 $(814)$ の太政官符の中で引用された天平 10 年 (738) 5 月 28 日付の格によると、国司が国司館を意に任せて造営し、国司
館で一人の病死があると、不吉で居住に適さないとしていた。これ を国図に揭載して進上するものを除くほかに、欲しいままに、場所 を移して造営することを禁じ、破損に応じて修理することと改めた。 太政官符（弘仁 5 年（814）6 月 23 日『類聚三代格』所収） 禁制国司任意造館事

右太政官去四月廿六日下五畿内諸国符偁。検天平十年五月廿八 日格偁。国司任意改造館舎。儻有一人病死。諱悪不肯居住。自 今以後。不得除載国図進上之外輙擅移造。但随壊修理耳者。(後 略)

やはり、この天平 10 年の格からも、この時期には建物の維持管 理に対する概念が影在化していたと判断できる。この時期には国分 寺が未整備のため、整備済みの国庁で法会が行われており、こうし た官衙の整備の進捗が、建物の維持管理の必要性を高めた一因と考 えられる。

このように、天平期には、官衙や寺院において一定の建物の整備 が進み、法的な整備はともかくとしても、維持管理に対する意識が 高まったのである。

国分寺については、造立計画当初に建物の維持管理の意図は見え ず、天平神護元年（766）9月 5 日付の勅（『続日本紀』）で、実態 調査を図り、天平神護 2 年（767）8 月 18 日付の太政官符 (『類聚 三代格』所収）で、造寺料をもって、修理するように指示した。こ れには全国規模の国分寺造営という事業の大きさに対し、新規造営 の進行が優先され、経済的に建物の維持管理を計画する余裕がなか ったことが背景にあり、その概念が存在しなかったのではないと考 えられる。現に、多くの国分寺の完成後、まもなく修理料として造 寺料が当てられており、建物の維持管理に対する配慮が窅える。

このように軍事施設の維持管理に関しては 7 世紀後半の段階から みられるが、それ以外の建物の維持管理に対する公的概念は養老律 令が撰定された養老期には見られず、個別の事例に対応した一時的 な修理に留まっており、天平期に計画的な維持管理の顕在化が確認 された。そして 8 世紀後半に入り、国分寺の整備とともに、建物の 維持管理が公的概念として定着し、これ以降は寺院・社寺・官衙を 中心に、建物の維持・修理が求められ、その対象は地方に及んだの である。

\section{3. 修理の体制・組織}

\section{1. 修理司成立以前の修理体制}

前項でのべたように、天平期以降、維持管理の建物の維持管理に 対する公的概念が窅え、奈良時代後半には公的概念として、維持管 理が求められた。その対象は主に地方で、責任を国司・郡司らに負 わせることが多く、貞観 11 年 (869) の大地震後に臨時に設置され た「陸奥国修理府」(『三代実録』貞観 12 年（870）9月 15 日条) などを除き、建物の維持管理・修理に対する組織的な関与は見出し がたい。

これに対し、中央では平安時代には、新造を目的とする木工寮と は別に、修理を主目的とする修理職が設けられた。また奈良時代に も、修理の役目を有したとみられる任官記事があり、修理を本務と する修理組織注 12 2) の存在が突える。この修理組織は、後述のよう に「修理司」という官司名と推察される。本稿では、この奈良時代 の修理司の存続時期や組織の格及び修理司以外の修理の状況を明ら 
かにしたい。まずは修理司成立以前における修理体制を検討しょう。

『続日本紀』宝亀 6 年（775）8月 22 日条に伊勢神宮の修理のた め、臨時に「使」が送られたことが確認できる。

この記事によると、暴風雨により、伊勢・尾張・美濃の国分寺や 諸寺・官舎などの建物に甚大な被害が生じ、この災害に対し、臨時 に「使」を派遣し、伊勢の斎宮を修理するとともに、諸国の人民の 被害状況を調査させた。ここで国分寺や諸寺の塔・官舎の修理に対 しては人員の派遣がなく、斎宮の修理にのみ、「使」が送られており、 その特殊性が表机ている。もちろん斎宮という施設の重要性もあろ うが、あくまで国分寺や諸寺の塔・官舎が国司・国師・郡司のもと で維持管理されていたのに対し、斎宮は、これらと別の管理体制下 であったためであろう。同様に次の伊勢神宮の修理の際にも「使」 の派遣が確認できる。

『続日本紀』延暦 10 年（791）8月 14 日

詔遣参議左大弁正四位上兼春宮大夫中衛中将大和守紀朝臣古佐 美。参議神祇伯従四位下兼式部大輔左兵衛督近江守大中臣朝臣 諸魚。神祇少副外従五位下忌部宿祢人上於伊勢太神宮。奉幣帛。 以謝神宮被焚焉。又遣使修造之。

延暦 10 年（791）8月 3 日の盗人による伊勢神宮の放火に対し、 参議を含む 3 人の高官を派遣し、幣帛を奉らせ、伊勢神宮に放火の 謝罪を行った。そして「使」を派遣して、これを修理させた。使者 の高官の名は記されるのに対し、「使」の人名が記されず、修理にあ たつたことから、低位階の技術官人の可能性が推察される。

いずれの史料においても、「使」は臨時に京外に派遣され、修理を 担ったにすぎず、また修理を専門とする任官ではなく、一時的な任 務に伴う任官である注 13 )。修理専門の職務名は次の史料に確認でき る。

『続日本紀』天平神護元年（764）3 月 10 日

大宰大武従四位下佐伯宿祢今毛人為築怡土城専知官。少武従五 位下采女朝臣淨庭為修理水城専知官。

この記述によると、大宰大戴の佐伯今毛人が築怡土城専知官に任 じられ、大宰少武の采女朝臣淨庭が修理水城専知官に任じられた。 この任官は、兼任であるが、水城の修理に専門にあたる役職名が確 認できる。天平勝宝 8 歳（756）には、関係の悪化した新羅討伐の 準備や大陸からの脅威への対抗として、怡土城を吉備真備に築かせ ており、水城の修理もこれに関連するものであろう。しかし築城や 修理に対する組織や実働人員の確保は確認できないことから、臨時 の役職とみられ、恒常的な維持管理ではなく、また修理に対する十 分な組織体制が整備されたとは考えにくい。佐伯宿袮今毛人、采女 朝臣淨庭はともに大峷大武、大宰少武と併任であり、この状況をみ るに、大宰府の組織を利用して、造営・修理にあたったと推察され る。すなわち、修理に対する専任者の例として重要であるが、独立 した修理組織に基づく、組織的な修理に対する取り組みではないと 判断される。

このように 8 世紀前半には維持管理・修理に対する組織化は確認 できず、一時的な赴任である「使」で対応していた。また 8 世紀の 後半に入り、水城という軍事施設の修理であるが、専任者が任じら れた。この時期は、国分寺の維持管理が定められた時期であり、こ うした状況は、前稿で指摘した、維持管理に対する法制や体制が生 まれつつある時期ともリンクしている。なお建物・施設の維持管理
に関する記述は地方における修理に限定されており、中央では確認 できない。こうした状況からみると、中央では、平安時代に木工寮 が修理を担ったように、修理専門の組織ではなく、造営官司が修理 を兼㸚た可能性が考えられる。

\section{2. 修理司の成立と規模}

「修理長官」・「修理次官」の任官に関する記述は『続日本紀』に 見られ、これは修理の専門組織の存在を示している。この修理組織 について、太田博太郎氏は平安時代の「修理職」にあてているが、 大夫・亮とあるべきところが、長官・次官という任官を不審とする 注 14 )。この修理組織に対する詳細な検討は、松原弘宣氏によるもの

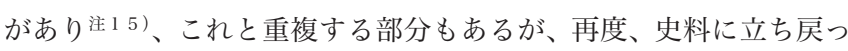
て検討しょう。

この修理組織については、『続日本紀』にみえる四等官制による任 官や西隆寺出土木簡に示される長官・次官 (二員) ・判官・史生・司 工・民領という記載に限られるが注 1 6)、これらより修理を専門とす る組織的な体制の存在がほぼ明らかである。特に西隆寺出土木簡に は「修理司」と記されており、この木簡の名称をもとに官司名が推 断されている。本稿では、この修理司の任官記事を中心として、改 めて存続期間を検討し、さらに官位相当から、修理司という組織名 とその格について一考を案じたい。

\section{2. 1. 存続期間}

『続日本紀』によると、従四位上伊勢朝臣老人が修理長官を神護 景雲 2 年（768） 7 月 17 日から務めている。宝亀 2 年（771）正月 23 日条には、中衛員外中将に加え、皇后宮亮としており、修理長官 の職は見えないが、宝亀 9 年（778）3月 10 日には、修理長官・遠 江守に加えて、中衛中将を併任したことが記され、ここまでは、修 理長官の職にあったと推察される。その後、伊勢朝臣老人は、天応 元年（781）5月 7 日には主馬頭に任じられており（修理長官の併 任は不明)、延暦元年（782）閏正月 19 日には散位で、遅くともこ れまでに修理長官の職を解かれた。

宝亀 9 年（778）の任官記事以降、弘仁 9 年（818）の修理職の設 置まで、修理司に関する記述は見られない。なお伊勢朝臣老人は造 西隆寺長官や木工頭も務めており注 1 7)、造営に関わる経歴が確認で きる。

同様に、次官についてみると、神護景雲 2 年（768） 7 月 17 日に 伊勢朝臣老人の長官就任と同時に、相模宿祢伊波が次官に任じられ た。彼は、相模国の有力豪族で、「私仏所」という民間工房を有する 人物であった。

また神護景雲 3 年 (769) 6 月 24 日に大外記従五位下池原公禾守・ 左大史外従五位下堅部使主人主を修理次官（併任）としたこと、宝 亀 3 年（771）11月 1 日に外従五位下軽間連鳥麻呂を修理次官とし たことが『続日本紀』に記される。なかでも軽間連鳥麻呂は大安寺 の造寺大工であったことが知られ注18)、実務能力を有した人物であ つた。その後、宝亀 5 年（774）9月 4 日には周防掾外従五位下英 保首代作を修理次官の併任としたが、英保首代作も西大寺に兒率天 堂の建造により、位階を賜っており注19)、造営で功を成した人物で あった。このように次官には、建築の実務能力を有した人材が当て られた。

これらの任官記事から修理司の存続期間を検討しょう。この存続 期間について、渡邊保忠氏は断続的と判断しているが、その根拠を 
明示していない注 20$)$ 。対して、松原弘宣氏や東野治之氏は少なくと も、神護景雲 2 年 $(768)$ から宝亀 9 年 (778) の継続的な存続を唱 えており、ともに西大寺・西隆寺の造営を契機として修理司が設置 されたとする注 21 1)。筆者も、すべての任官が六国史に記されるわけ ではなく、修理司廃止の記事がない以上、継続的に存続したと考元 る。ただし、宝亀 9 年 (778) 以降も一定の期間、修理司は存続し、 以下のように、他の造営官司の統廃合に伴い、廃止されたと考える。

伊勢朝臣老人は延暦元年 $(782)$ 閏正月 19 日に散位で、ほかに長 官の任官者が見えないことから、この頃までに修理司は廃止された と推察する。当時の状況を見ると、天応元年 (781) 6 月 1 日には、 桓武天皇が定員外の官人を全廃しており(『続日本紀』)、修理司以外 の造営関係の官司をみても、天応 2 年（782）に造宮省・造法華寺 司が廃されている。そして延暦 3 年 (784) に造長岡京使が設置さ れており、再び、維持管理から新規造営へ軸足が移された。こうし た官司改編の中で、修理司も廃されたと考えられるのである。

\subsection{2. 職務}

奈良時代の中央における修理の対象は、宮内及び京内である。こ

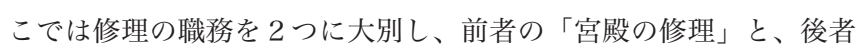
の京内のうち、公的な部分である「坊城の修理」を官司による修理 の職務と捉え、これらの官司ごとの分担をもとに、修理司の職掌に ついて検討したい。

東野治之氏は修理司の職務を西大寺・西隆寺の造営にともなう京 域北部の条坊整備とみる。これに対し、松原弘宣氏は、東大寺や唐 招提寺造営の際には、同様の条坊整備のための修理司やそれに相当 する官司が設置されない点、条坊整備を主たる任務とするには名称 が不審である点などから、東野説に否定的で、西大寺・西隆寺造営 を契機として、宮内・京内の修理一般を掌るために修理司が設置さ れた可能性を提案している。

筆者は、基本的に松原説に賛同するが、以下のことから、奈良時 代の修理司の職務に条坊の修理を含める点は、疑問である。近年の 発掘成果を加え、検討したい。

「坊城の修理」についてみると、平安時代には、基本的には京職 がその役を担っており、修理坊城使が設置された時期にも、京職に 一定の責務が課せられていた。京職は本来、左京職、右京職の 2 つ に分か水て、京師の行政、司法、民政、警察などのことを司った役 所で、修理の専任の役所ではない。ただし、『軍防令』によって、軍 事に関わる施設の維持が軍団に課された例や『延喜式』によって、 衛門府による守屋の修理が定められた例のように注 22 2)、営繕官司以 外の統括官司が管轄内の施設の維持管理を担うこともあり、京職に よる坊城の修理もこれらと同様と考えられる。このことからも、元 来、すなわち奈良時代においても、恒常的なインフラである坊城の 修理の責は、京職にあったと推察される。

さらに、近年の西大寺食堂院の発掘調査により、西大寺造営にと もなう北辺坊の整備に対して、疑問を投げかける成果が報告されて いる。

発掘成果によると、西大寺の寺地が少なくとも食堂院の北方では 北辺坊に及ばず、また北辺三坊三坪が奈良時代の前半・後半ともに、

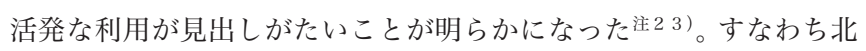
辺坊自体の整備も疑わしく、西大寺造営にともなう坊城の整備が、 修理司の職務として重視されたとは考え難いのである。また西大寺
や西隆寺の造営の際に坊城の修理・改変をともなったとしても、造 西大寺司や造西隆寺司が設置された以上、これらの機関が坊城の整 備を担うと考えられ、松原弘宣氏も指摘するように、他の官大寺造 営において、同様の修理司が置かれなかった点と整合がとれない。 この 2 点から、修理職の職務に「坊城の修理」を積極的に含める根 拠は見出しがたいのである。

次に「宮殿の修理」の状況についてみると、奈良時代には木工寮 の実務稼働は確認できず、建築技術者を一元的に集約した木工寮か ら、他官司・各現場に技術者が派遣されており、木工寮は実務機関 ではなく、行政機関であった注 2 )。そのため木工寮が修理の役目を 担うことは難しく、造宮省が修理していたことが確認でき、他の造 営官司についても同様に修理の任を担つたと考えられる。

こうした状況から、西大寺・西隆寺の造営に伴う京職の修理職務 の増加は文献史料に確認できず、西大寺造営にともなう北辺坊整備 という根拠も発掘調查からは明示できない。「坊城の修理」よりも、 むしろ建物の修理については、宮内・京内における臨時の造営量の 過大により、造宮省の修理職務に手が回らなくなったということが 背景にあるのではなかろうか。

実際に、井上薰氏は造宮省の造営現場において、衛士が従事した と指摘している。その概略は以下のとおりである。衛士の定員は左・ 右衛士府に各 800 人であり、右衛士府からの食料請求文書によると 定員の 800 人に近い 791 人である一方、左衛士府からの食料請求文 書は存在しない。そ机に対して造宮省からの食料請求文書の人数は 795 人で、左衛士府の人数と近い。これより造宮省からの文書は、 左衛士府の衛士の食料請求文書と考え、これより実際の作業にあた つたのは左衛士府の衛士と推定している注25)。これは造宮省の繁忙 を裏付けるものである。

このように「坊城の修理」と「宮殿の修理」の状況、すなわち西 大寺・西隆寺の造営時に、坊城の整備の必要性がみられず、本来、 担うべき京職が存在したこと、さらに造宮省が労働力を他官司より 得ており、宮殿の修理はおろか、造営の実務に支障をきたしていた ことから、修理司の修理対象は、京職が担っていた坊城ではなく、 繁忙により、造宮省による修理が困難となった宮殿が主な対象と推 察できるのである。

\section{3．2．３．官位相当と格}

官位相当から修理司の組織の格をみると、長官が従四位上、次官 が外従五位下で、中宮職や左右京職よりも高い位階である。なお平 安時代の修理職の位階をみると、大夫を従四位下相当、亮を従五位 下相当としており、木工寮の頭の従五位上、助の正六位下よりも高 (注 2 6)。むしろ、長官の四位、次官の五位という官位相当は省に準 じた造東大寺司に近い。

このように奈良時代の修理組織名については、長官・次官という 四等官制を鑑みるに、西隆寺出土木簡に記されるように「修理司」 で、その格は造東大寺司と同じ「司」でありながら、任官者の位階 相当から、最低でも「職」以上と推測される。

\section{3. 修理司の廃止以降}

維持管理に関する状況は、平安時代に入ると造営体制の大改編に ともなって一変し、明確に修理を専任とする役所として修理職が設 けられた。また修理坊城使という名も 9 世紀の史料に見え、これら の組織の関係や系譜について一考を案じたい。ここでも「宮殿の修 
理」と「坊城の修理」の官司ごとの職務の分担を絡めて検討する。

『国史大辞典』によると注 27)、修理職は皇居などを造営した令外 の官で、同時期の造営官司を見ると、延暦元年（782）に造宮省を 廃止し、同 15 年（796）頃に造宮職を置き、同 24 年（805）に造 宮職を廃して、木工寮に属させた (『日本後紀』天長 $2 \cdot 3$ 年 $(825$ ・ 826）頃の太政官符）。しかし、木工寮が繁忙であるため、弘仁 9 年 （818）７月頃に修理職を置き、造宮職の任務を司らせたが (『類聚 国史』、弘仁 9 年 (818) 7 月 19 日付の太政官符など)、天長 3 年 (826) に修理職を廃止し注 28$) 、$ 木寮に属させた。のちに、再度、修理職 が置かれたが、これは史に漏れており、寛平 3 年（891）8月 3 日 の太政官符に修理職の官位を定めることが記され、その後は常置さ れ、木工寮と修理職による併立が定まった。

修理職に関しては、渡邊保忠氏・太田博太郎氏による指摘がある。 渡邊保忠氏は律令体制下における造営組織の変遷を述べる過程で、 修理職を、修理坊城使・造京省などの京域の造営を担う官司との関 係性を図表中で示唆している注 29)。また延喜式をもとに、木工寮と 修理職の工人構成の比較を行っており、技術官人である大工・少工 や事務官人である大允・少允が置かれず、造営計画の中枢ともいう べき彼らが不在で、長上工や将領などの現場指導者を主体として構

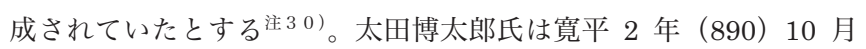
30 日に修理坊城使の廃止にともなって、修理職を設置したとする注 $31)$ 。

修理左右坊城使はその役職名から、修理の対象は坊城、すなわち 都城の坊ごとにその周囲に迴らせた垣やそれに伴う溝、道路で注 32 2)、 構造体として強固である垣は、恒常的な設備と位置づけられ、その 維持管理のための組織が早い時期に設置されたと考えられる。

修理坊城使は仁寿 2 年 (852) に廃され、木工寮へ隷属し、同年 の太政官符（斉衡 2 年（855）9 月 19 日付太政官符『類聚三代格』 所収）には、坊城の修理に関し、「理損之色」の修理を木工寮、「非 理之損」の修理注 33 ) を京職と分担が定められた。しかし実際には 木工寮が坊城の修理をすべて行っていたようである。その結果、修

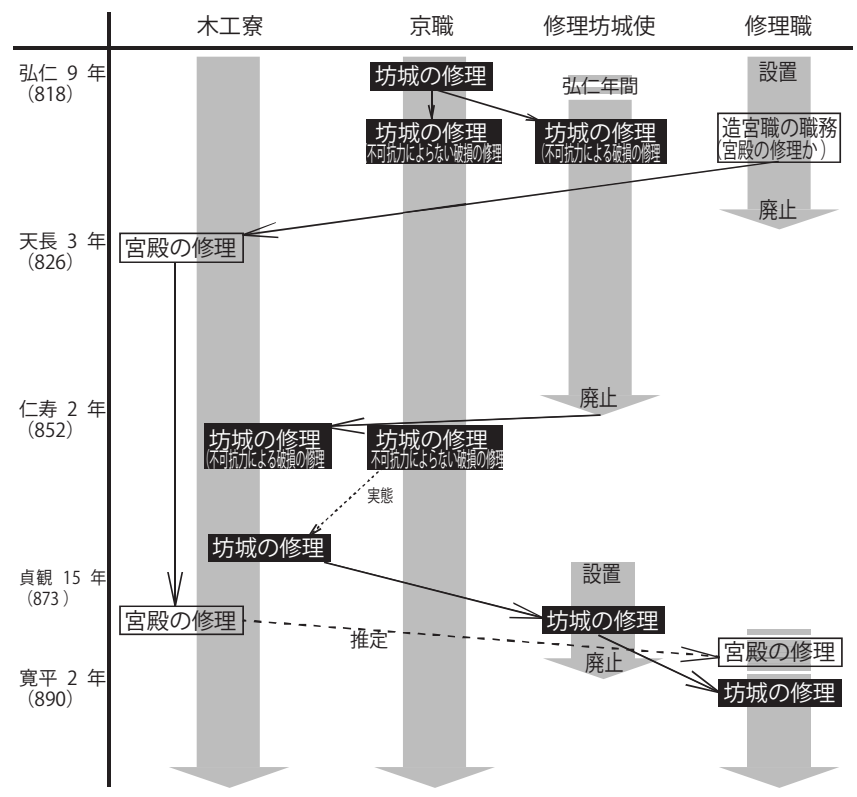

図 1 造営・修理の組織変遷と修理職務の分担 (注 1 渡邊論文を一部、参考とし、筆者が新たに作成した)
理職の置かれなかった、この時期には、宮殿・坊城ともに、すべて の修理が木工寮に集約していたのである。こうした状況から、木工 寮は繁忙を極め、坊城使を再度、設置するに至った注 34 )。

修理坊城使の廃止については、先行研究では修理坊城使に代わつ て、修理職を新設したとするが注 35 )、次の『日本紀略』の記述を再 検討し、修理坊城使を修理職へ併合した可能性を指摘したい。

『日本紀略』寬平 2 年 (890) 10 月 30 日条

其日。停修理左右坊城使。併修理職。

この記事は、修理坊城使を廃止し、修理職に併合したことを記し ている。つまり、この時には修理職が存在し、修理坊城使とは異な る職務を有していたと判断できる。すなわち、修理職には本来の職 務があり、修理坊城使の統合により、坊城の修理という職務が付加 されたと推察されるのである。もちろん『日本紀略』の史料的性格 を考慮する必要があるが、後述の職務の分担を鑑みると、修理職は 寛平 2 年時にはすでに設置されており、その本来の職務は「宮殿の 修理」と考えられる。修理職の職務である「宮殿の修理」が木工寮 から修理職へ移諒した記述はこの史料以外にもなく、「併」は誤字で はなく、「宮殿の修理」の職務を有した修理職への併合と素直に解釈 すべきである。

以上の修理職・修理坊城使の統廃合の整理から、木工寮とこれら の官司による修理の職務分担の経緯をまとめたものが図 1 である。

\section{4. 修理の職務の分担}

後世の修理職が建築修理の役割を多く担う状況からみて、果たし て、都城のインフラ整備を主とする官司である修理坊城使の継承と 捉えてよいのであろうか。改めて、修理職の設置の経緯や職員配置 を整理し、その性格を明らかとし、宮殿の新築、修理、坊城の修理 という 3 つの職務を通じて、官司の統廃合から木工寮・修理職・修 理坊城使・京職の分担を検討したい。

まず修理職の設置の記述には、職務に関する言及はないが注 36 ）、 修理職の性格を示す史料として、造宮職の職務の継承注 3 7) に関す る記述のほか (『類聚国史』、弘仁 9 年 (818) 7 月 19 日付の太政官 符など)、『日本後紀』弘仁 13 年 (822) 7 月 8 日条に算師が修理職 に置かれたことが記される。算師は主計寮・主税寮などに配され、 その後、木工尞や造宮省など、予算策定や労働力の算定が必要な限 られた官司にのみ配された人員である注38)。

この算師の配置から、修理職の職務として、修理の実務のみを下 請けするのではなく、実質的な計画的修理やそれに伴う予算策定が 必要であったと判断でき、恒常的かつ組織的な維持管理の実情が表 れている。

改めて、組織の統廃合とともに、修理の職務の分担について整理 しょう。まず、木工寮と修理職が併立した、弘仁 9 年 (818) 〜 天 長 3 年（826）頃には、前述のように修理職は造宮職の職務を担つ ていた。造宮職の職務は宮城の造営・修理であり、修理職はこのう ちの「宮殿の修理」を担い、「坊城の修理」については、本来の職務 である京職がこれを担ったと推察され、京職と修理坊城使が併立し た弘仁年間〜仁寿 2 年 (852) には注39)、不可抗力による修理を修 理坊城使、不可抗力によらない修理を京職が担っており、木工寮の 修理は宮殿に限られていた。

修理坊城使の廃止後は、仁寿 2 年 (852) の太政官符（斉衡 2 年 （855）9月 19 日付太政官符『類聚三代格』所収）によると、京職 
と木工寮で坊城の修理を分担したが、実際にはすべて木工寮が修理 を行っていた。

こうした状況から、貞観 15 年 (873) 以降は再び、木工寮と修理 坊城使を併立させたが、これも天長 3 年 $(826)$ ～仁寿 2 年 $(852)$ の状況と変わらず、木工寮に「宮殿の修理」という大きな負担が依 然として残っていた。

こうした状況は、再度、修理職が設置されたことにより打開され た。この設置時期は明らかではないが、これを機に、木工寮は修理 の職務を宮殿・坊城ともに修理職と修理坊城使へそれぞれ移譲し、 修理坊城使の廃止に伴って、修理の職務を修理職に一元化させたと 推察できる。すなわち、この寛平 2 年（890）の修理坊城使の廃止 の時点で、木工寮には修理の負担がすべて取り除かれており、木工 寮による新造と修理職による修理という体制が築かれたのである。

このように職務の分担を概観すると、元来、修理自体は木工寮の 職務であったが、宮殿の修理・坊城の修理のうち、どちらか一方を 木工寮以外の組織に移譲させるために、修理を職務とする様々な組 織を別置したが、いずれも不調に終わり、結局、9 世紀後半に、両 者の修理の職務を、ともに修理職へ集約したことで、ようやく木工 寮の職務の負担が組織相応に軽減され、2 組織による職務分担によ って、安定した体制が確立したのである。

\section{4. まとめ}

以上、文献資料をもとに、建物の維持管理に対する公的概念の萌 芽及び修理組織とその職務を明らかとした。天平期に建物の維持管 理に対する概念の顕在化が確認できるが、実質的な法的整備は遅れ、 奈良時代後半に入って、計画的な維持管理に対応するため、修理組 織として修理司がはじめて組織された。この組織の実態は不明であ るが、少なくとも、神護景雲 2 年（768）から天応元年（781）頃ま で存続しており、その四等官制から組織の格が「省」に近いと推察 できた。また修理司の成立以前には、主に地方の個別の災害などに 対応するために、一時的な修理の任を有した「使」や修理専門の「専 知官」を任じて、維持管理に当たっていた。

平安時代については、修理職・木工寮・京職・修理坊城使の関係 性を踏まえ、修理に関わる組織の統廃合を再整理した。官司ごとの 修理職務の分担を通して、その責務移譲と組織改編の関係を示し、 最終的に修理の職務をすべて木工寮から取り除き、修理職へ移すこ とで、両組織の併立により、安定体制の構築を図っていたことが明 らかとなった。

ただし、これらの中央における修理司や修理職は、ともに宮殿や 坊城を対象とした組織であり、宮殿以外の修理に対する組織の設置 は見られない。すなわち中央の大寺・地方の寺社のいずれにおいて も、修理に対する財源は確保されたが、基本的には修理に対する公 的組織は設置されなかったのである。中央大寺に関しては、造寺司 の廃止以前には、これが修理を行ったのであろうが、その廃止後の 建物の維持管理には支障をきたしたと推察される。こうした背景が、 平安時代の寺院内に造寺所を生从出していった一因として存在した のではないだろうか。この点については、平安時代の造営（新造） の体制を含め、今後の検討課題としたい。

附記
本研究は JSPS 科研費 $26709044 \cdot 26630288$ (ともに研究代表者海 野聡) の研究成果の一部である。

注

注 1 ）太田博太郎「上代の営繥官制」『日本建築学会研究報告』6 号 1950 年（『日本建築の特質』岩波書店 1983 年所収）、同「造寺司と木工寮」 (『日本建築の特質』) (『日本建築史序説増補第 2 版』彰国社 1989 年所 収）、渡邊保忠「律令的建築生産組織」『新訂建築学大系』4-I 日本建築 史、彰国社 1968 年、同「日本に打ける古代的建築生産構造とその中世一 の発展過程について」『建築䧴誌』67-788 号、1952 年 (ともに『日本建 築生産組織に関する研究』明現社 2004 年所収）福山敏男「奈良時代に於 ける法華寺の造営」及び「奈良時代に於ける石山寺の造営」『日本建築史 の研究』桑名文星堂 1948 年（綜芸舎 1983 年再版）ほか。

注 2）大岡實『南都七大寺の研究』中央公論美術出版 1966 年、宮本長二 郎「奈良時代における大安寺・西大寺の造営」『日本古美術全集』6 巻、 西大寺と奈良の古寺、集英社 1983 年ほか。

注 3 ）松原弘宣「修理職についての一研究」『ヒストリア 78』1978 年

注 4）海野聡「国分寺伽藍の造営と維持システムについて」『日本建築学 会計画系論文集 660 2011年。

注 5 ）海野聡「古代日本における建物に対する認識と記述方法一建物の認 識・評価に関する歴史的研究その 1 一」曰日本建築学会学術講演大会』2013 年。

注 6 ）海野聡「古代日本における建物の維持管理に関する法的規定」『日 本建築学会計画系論文集 705』2014 年

注 7）注 6）前掲論文。

注 8 ）『国史大辞典』大宝律令（たいほうりつりょう）の項。

注 9 ）『国史大辞典』養老律令（ようろうりつりょう）の項。

注 10 ） 注 8) 前揭の項。

注 111 ）『国史大辞典』例（れい）の項。

注 12 2) 本稿で修理司とする修理を司った官司に関しては、『国史大辞典』 修理職（しゅりしき）の項に以下の記述が見える。『続日本紀』の神護景 雲 2 年 $(768)$ から宝亀 9 年 (778) にかけてみえる修理長官・次官の詳細 は不明であるが、造宮省の職務のなかの皇居造営をつかさどったと推定さ れるとする。

注 13 ）「使」に関しては、石山寺の造営の際に、「斧修理使」が一時的 に斧の修理のために、造石山寺所から山作所へ送ることが画策された（天 平宝字六年（762）3月 4 日「造石山寺所符案」『大日本古文書』編年 15 ノ 158）。「造宮使」（『続日本紀』天平宝字 5 年（761）10月 28 日条）・ 「造長岡宮使」（『続日本紀』延暦 3 年（784）6月 10 日条）など、宮殿の 改作や造営の例も見られる。これらの派遣も一時的な任務・出向で、「使」 は目的をもって、派遣される役目であったと考元られる。

注 14 ）太田博太郎「上代の営䋨官制」（注 1 前掲論文）

注 15 ) 注 3 前掲論文

注 16 ）西隆寺調査委員会『西隆寺発掘調査報告』1976 年

注 17 ）伊勢朝臣老人は修理長官の任官後、晚年に正四位下で木工頭に任じ られており、実態としては令内官司の木工寮の位置づけは高かった可能性 がある。

注 18 ）『続日本紀』神護景雲元年（767）3月 9 日条

注 19 )『続日本紀』宝亀 2 年 (771) 10 月 27 日条

注 $200 ）$ 渡邊保忠「律令的建築生産組織」（注 1 前揭論文）

注 21 ）注 3 前揭論文、東野治之「木簡からみた西隆寺造営」『西隆寺発 掘調查報告』 (注 16 前揭書)

注 22 ）「延喜左右衛門府式」

凡宮城諸門守屋者。各本府修造。

注 23 ） 以前は、西大寺の寺地が北辺坊に展開する可能性も指摘されてお り、これらの背景から、西大寺の造営により平城京の北辺坊が整備され、 これにともなって修理司が設置された可能性が指摘されていた。ただし発 掘調查により、食堂院の北門 SB975 を一条大路の南側溝の南方で検出し、 また北辺三坊三坪では奈良時代前半・後半ともに顕著な遺構が確認されな かった（『西大寺食堂院・右京北辺発掘調査報告』奈良文化財研究所 2007 年）。もちろん、北辺三坊三坪以外の北辺坊に西大寺の寺地が展開した可 能性もあるが、現状の発掘成果からは、西大寺造営にともなう北辺坊の開 発を積極的には支持しがたい。

注 24 ）海野聡「司工の能力とその支配」『奈良時代の造営体制と建築』 私家版 2013 年東京大学学位請求論文 
注 25 ）井上薰「造宮省と造京司」『日本古代の政治と宗教』吉川弘文館 1961 年

注 26 ）和田英松『官職要解』講談社 1983 年

注 27 ）『国史大辞典』修理職（しゅりしき）の項。

注 28 ）斉衡 2 年（855）9月 19 日付太政官符（『類聚三代格』所収）

注 29 ）渡邊保忠「律令的建築生産組織」（注 1 前揭論文）。同論文の本 文中では、修理坊城使と修理職の系譜、あるいは継承について直接的な言 及はないが、図表中で「造京使～修理職」「修理左右坊城使 $\rightarrow$ 木寮」「修 理左右坊城使 $\rightarrow$ 修理職」の矢印を記している（建築学体系 4-I 日本建築 史 1-117 図、132 頁、日本建築生産組織に関する研究 1959、図 3-1、23 頁）。この図表の矢印に関する説明は見られないが、これは継承・系譜を 示していると考えられる。

注 30 ）＼cjkstart渡邊保忠「律令的建築生産組織」（注 1 前揭論文）

注 3 1 ） 太田博太郎「上代の営繥官制」（注 1 前揭論文）

注 32 2) 『日本国語大辞典』坊城使（ぼうじょうし）の項によると、坊城 の修理を担ったとする。

注３３）前者は災害など、不可抗力による破損の修理、後者はこれ以外の 破損による修理と推察されて抢り（注 3 前揭論文）、これは妥当な解釈と 考える。

注 34 ）『三代実録』貞観 15 年（873）10月 10 日

勅。左右坊城使。仁壽二年既従停廃。隷木工寮。今彼寮作事繁多。難耐兼 済。宜復舊置之。

なお『類聚三代格』巻 4 「廃置諸司事」にも同様の記述が見える。

注 35 ）太田博太郎「上代の営繥官制」（注 1 前揭論文）。太田博太郎氏 は『類聚三代格』巻 4 「廃置諸司事」の記述をもって、併合ではなく、新 設と判断した可能性があるが、不明である。また、この『類聚三代格』の 記述は、久損が多く、年紀も定かではなかったが、近年、狩野家本による 補訂により、年紀は貞観 15 年（868）10月 10 日と推定されている。これ に対し、『日本紀略』の仁和 3 年 (887) 以降の記述は、六国史の拔粋で はない点を考慮する必要があるが、年紀の明らかな『日本紀略』の記述は 信頼しうると考える。

注 36 ）『類聚国史』弘仁 9 年（818） 7 月 8 日（『日本後紀』逸文） 定木工寮史生六員。定修理職史生八員

注 37 ） 井上薰氏によると、造宮省は奈良時代を通じて、造営修理の常置 機関であったする（井上薰「造宮省と造京司」『日本古代の政治と宗教』 吉川弘文館 1961 年)。これに対し、造宮職の設置された平安京の時期に は、平城京とは異なり、京の造営機関が置かれなかった。松原弘宣氏はこ れをもって、造宮職が造京の役を兼ねたと推察する（注 3 前揭論文）。

注 38 ）算師は律令制において計数を掌る官職。主計寮・主税寮・大宰府 に設置された。後に木工寮・造宮省など、造営に関わる役所にも令外官と して設置された（『国史大辞典』算師（さんし）の項）。

注 39 ） 渡邊保忠氏は、修理職の設置（天長 3 年）にともなって修理左右 坊城使が廃止され、天長 8 年 (831) 年に再度、設置されたと判断してい る (注 1 前掲論文) 。この判断は天長 8 年 (831) 12 月 9 日付の太政官符 （『類聚三代格』所収）「応左右坊城使并侍従㕌防鴨河暮野河両所五位以下 別当四年遷替兼責解由事」に基づくと考えられるが、この史料は長官であ る別当の任期を 3 年から 4 年に変更したという内容で、修理左右坊城使の 新設を示す太政官符ではない。また天長 3 年 $(826)$ に修理坊城使が廃止 されたことを示す史料もなく、むしろ任期の変更ということを鑑みると、 存続していたと考えられる。 


\section{THE GERM OF PUBLIC CONCEPT FOR BUILDING MAINTENANCE AND ITS ESTABLISHMENT IN ANCIENT JAPAN}

\section{Satoshi UNNO*}

* Nara National Research Institute for Cultural Properties Researcher, Dr. Eng.

*Nara National Research Institute for Cultural Properties Researcher, Dr. Eng

This study aims at the germ of public concept to building maintenance and its organization in ancient Japan. Previous studies took particular note on the new construction of architecture, and paid little attention to building maintenance.

Needless to say, new construction was important activity, but building maintenance was as important as new construction. Because long time use of building requires regular maintenance, so the legal rules were established in 8th century Japan. Against such background, I illuminated the legal rules of building maintenance in ancient Japan through my previous study. Under these circumstances, the aims of this article are below.

1. The resolution of the germ time of public concept to building maintenance

2. The establishment of maintenance in ancient period and its role content

As a result, the public concept of building maintenance appeared in Tenpyo Period, and building maintenance organization was established in the latter half of Nara period. The actual condition of this organization was unknown, but it persisted from 768 to 781 . I can analogize the scale of this establishment through its appointment.

In addition to this, it was confirmed temporary detachments to correspond to individual disasters, before the establishment of this organization.

As well as this, I re-assembled documents about unification and abolition of construction organization in Heian Period. Then through the burden sharing of building maintenance, I revealed the movement of authority and reorganization. Finally, the authority of building maintenance was moved to Surishiki(修理職) from Mokuryo(木工寮), then this stable twin organizations continued on a long-term basis.

Although such organizations were established for central government and there was no organization in temple and in rural area. That is to say, in such area, the financial resource of building maintenance was secured, but any public maintenance organizations were not established. 